\title{
AKR7A2 Gene
}

National Cancer Institute

\section{Source}

National Cancer Institute. AKR7A2 Gene. NCI Thesaurus. Code C21309.

This gene is involved in the detoxification of xenobiotics. 